\title{
EPALLAGIDAE VERSUS EUPHAEIDAE REVISITED
}

\author{
Günter Bechly \\ Staatliches Museum für Naturkunde, Abt. Paläontologie, \\ Rosenstein 1, D-70191 Stuttgart, Germany. \\ (e-mail bechly@gmx.de)
}

Received 22 Februari 1999; revised 20 March 1999; accepted 21 March 1999

Key words: Odonata, taxonomy, family-group, legions, Selys, Epallagidae, Euphaeidae, Heliocharitidae, Dicteriadidae.

\begin{abstract}
The author's previous rejection of Selys' legions as available family-group taxa is restated and elaborated, strictly based on the provisions of the International Rules of Zoological Nomenclature (4th ed.).
\end{abstract}

\section{Introduction}

In my paper on amber damselflies and fossil Epallagidae (Bechly, 1998) I recently discussed the taxonomic problem of the odonate family-group taxa based on Selys' legions. Because of the relevant regulations of the Code (Art. 11.7. IRZN) I came to the conclusion that Selys' legions are not available as family-group taxa. As a consequence, I proposed that Epallagidae Needham, 1903 has priority over Euphaeidae Jacobson \& Bianchi, 1905 (nec Selys, 1853), and Heliocharitidae Tillyard \& Fraser, 1939 has priority over Dicteriadidae Montgomery, 1959 (nec Selys, 1853) (contra Dunkle, 1991).

To my surprise this issue seems to have stirred up a rather vivid debate among some fellow odonatologists. Some of them suggested to me an alternative interpretation of the referring article of the Code, claiming that the "overriding principle of stability should apply" in this case instead of "nitty-gritty priority seeking".

\section{Discussion}

Here, I take the opportunity to further explain my view:

1) In fact there is no serious taxonomic problem involved that requires any "overriding principle of stability". Most family-group names that were based on Selys' legions are perfectly valid names, though not under Selys' authorship. The only three exceptions known to me, are the "legion Podagrion", the "legion Euphaea" and the "legion Dicterias". The "legion Podagrion" is obsolete anyway, since the generic name Podagrion is a junior homonym that was later replaced by Selys himself with Megapodagrion, so that the valid family-group name became 
Megapodagrionidae. In the case of the other two legions, the names Epallagidae and Heliocharitidae indeed get priority over Euphaeidae and Dicteriadidae (see above). However, this involves no taxonomic instability at all, since both names have been frequently used throughout this century and thus are as well known as the other two names. The only thing that changes in all other cases of family-group names based on Selys' legions, is the authorship of the taxa, but not the taxonomic names themselves. I regard the question of correct authorship of a taxon as a minor side issue that should not stir up "strong feelings". Though Selys certainly deserves the authorship from a historical point of view, considering his monumental pioneer work in odonate systematics, this is unfortunately not of any taxonomic relevance from the viewpoint of the rules of nomenclature.

2) The mentioned alternative interpretation of Art.11 by some fellow odonatologists suggests that I have only cited the first half of the referring Art.11.7.1.1. while the second half would allow one to infer by the context and the presumed intention of the author, that Selys' legions have to regarded as "nouns in the nominative plural". This is certainly incorrect. The second half of the mentioned paragraph only applies in those cases of doubt, in which the taxonomic name at least could be (grammatically) a noun in the nominative plural, but in which it is not fully clear if this is indeed the case and if this was really intended by the author. In case of Selys' legions this part of Art. 11 cannot apply, because a combination of a genus name with the word "legion" grammatically simply cannot represent a noun in the nominative plural. It would be different if Selys would have coined higher taxa names like Dicteriastidés or Euphaeaoidés (with French suffix), or likewise. Some other fellow odonatologists also claimed that Art.11.7.1.2. is what really matters, since this paragraph states that the name must clearly be used to denote a suprageneric taxon.

However, the fact that Selys' legions indeed meet this criterion is actually irrelevant, since Art.11.7.1. mentions four criteria that are all connected by the word "and", which means that all these four criteria must be fulfilled. Selys' legions only meet criteria (2) and (4), but fail to meet criteria (1) and (3), since they are neither nouns in the nominative plural, nor do they end in a latinized suffix. Art.11.7.2. indeed allows names that were published before 1900 to be accepted as family-group taxa, even if they do not meet the third criterion (3), and thus even if they do not end in a latinized suffix. However, one has to consider the precise condition for this exception. This part of Art.11 says "If a family-group name published before 1900, in accordance with the above provisions of this Article, but not in latinized from, it is available with its original author and date only if it has been latinized by later authors and has been generally accepted ...". This paragraph clearly states that this exception from the rule is only possible in cases where all other criteria (except 3: latinized suffix) are met. Since Selys' legions also fail to meet the criterion (1), this exception clause is not applicable.

Therefore, according to Art. 11.7. of the Code there is unfortunately no possibility to save Selys' authorship by any overriding principle. The Code only allows the suppression of senior synonyms in very exceptional cases (certainly not just to save 
someone's authorship) and only by a ruling of the Commission. Whether we like the result or not is of no importance in this affair. Those who are upset about this consequence should keep in mind, that if everybody were to be allowed to make his own rules of nomenclature or his private re-interpretations of the Code, the outcome would be a return to a taxonomic chaos that once was the reason for the creation of universally accepted rules of nomenclature. I do not agree with certain provisions of the current Code myself, but, unless they are officially changed, we have to live with them and strive to apply them correctly.

\section{References}

Bechly, G., 1998. New fossil damselflies from Baltic amber, with description of a new species, a redescription of Litheuphaea carpenteri Fraser, and a discussion on the phylogeny of Epallagidae (Zygoptera: Caloptera). International Journal of Odonatology, 1:33-63.

Dunkle, S.W., 1991. Review of the neotropical damselfly family Dicteriadidae (new spelling), with an annotated bibliography (Zygoptera). Odonatologica 20: 401-416.

Jacobson, G. \& V. Bianchi, 1905. [Die Orthopteren und Pseudoneuropteren des Russischen Reiches und der angrenzenden Gebiete]. A.F. Dewrien, St. Petersburg. [Odonata chapter pp. 635-952.

Montgomery, B.E., 1959. Geographical distribution of the New World calopterygine dragonflies, with notes on their evolutionary position. Proceedings of the XVth International Congress of Zoology, London: 1001-1003.

Needham, J.G., 1903. A genealogic study of the dragonfly wing venation. Proceedings of the U.S. National Museum 26: 703-764, pls 31-54.

Selys-Longchamps, E. de, 1853. Synopsis des caloptérygines. Bulletin de l'Académie Royale de Belgique 20(Suppl.): 1-73.

Tillyard, R.J. \& F.C. Fraser, 1939. A reclassification of the order Odonata based on some new interpretation of the venation of the dragonfly wing, 2. Australian Zoologist 9: 195-221. 